\title{
Novel terrestrial haul-out behaviour by ringed seals (Pusa hispida) in Svalbard, in association with harbour seals (Phoca vitulina)
}

\author{
Christian Lydersen ${ }^{a}$, Jade Vaquie-Garcia ${ }^{a}$, Espen Lydersen ${ }^{b}$, Guttorm N. Christensen ${ }^{c}$ \& Kit M. Kovacs ${ }^{\mathrm{a}}$ \\ aNorwegian Polar Institute, Tromsø, Norway; bUniversity College of Southeast Norway, Campus Bø, Norway; ' Akvaplan-Niva, Tromsø, Norway
}

\section{ABSTRACT}

Ringed seals (Pusa hispida) are the most ice-associated of all Arctic pinnipeds. In the Svalbard area, this species has always given birth, moulted and rested on sea ice. In addition, much of their food has been comprised of ice-associated prey. Recently, ringed seals have been reported to be using terrestrial substrates as a haul-out platform in some fjords on the west coast of Spitsbergen. In many cases the seals involved are harbour seals (Phoca vitulina), which are extending their distribution into new areas within the Svalbard Archipelago and which are being misclassified as ringed seals. However, this study reports that terrestrial haulout by ringed seals is also now taking place on rocks exposed at low tide as well as on the coastline. Recent intrusions of warm Atlantic Water (with associated prey) have extended deep into the fjords of western Spitsbergen, resulting in deteriorated ice conditions for ringed seals and expanded habitat for harbour seals. Over the last decade, ringed seals have become more and more confined in coastal areas to narrow bands in front of tidal glacier fronts where Arctic conditions still prevail. In one lagoon area, ringed seals are hauling out on intertidal mud flats in close association with harbour seals. Land can likely replace sea-ice for many of the ringed seals haul-out needs. However, for the small dry-cold adapted ringed seal pups that are normally born in snow lairs on the sea ice, terrestrial haul-out is unlikely to be a viable solution because of predation and thermoregulatory stress.

\section{KEYWORDS}

Arctic; behavioural plasticity; climate change; glacier fronts; lagoons; sea ice
Ringed seals (Pusa hispida) are the most ice-associated of the Arctic seal species; they are born on sea ice, they moult on sea ice, they rest on sea ice and they do much of their foraging in association with this habitat. In Svalbard, Norway, the prime breeding areas for ringed seals are land-fast ice areas in fjords that have active glacier fronts that protrude out into the ocean (Lydersen 1998). In such areas, ice pieces calved from the glaciers freeze into the sea ice in late autumn and early winter and snow accumulates in drifts around these structures to depths that allow ringed seals to dig out a lair in the snow over a breathing hole in the ice. Such lairs are constructed by adult ringed seals of both sexes and also by immature animals. The lairs provide shelter from harsh climate conditions (Smith et al. 1991) and also afford some protection from predation since it takes some time for a predator to dig or smash through the roof of the lair giving the seals some time to escape into the water through the breathing hole (Lydersen \& Gjertz 1986). Ringed seal mothers give birth to their young in these lairs. The lairs are vital for the survival of the pup that weigh only a few kilograms at birth. Each ringed seal has several breathing holes and lairs that it can move between if one structure is attacked. Mothers will move very young pups from lair to lair, but if she is out feeding, pups are at risk because they do not enter the water alone when they are very young (Lydersen \& Hammill 1993; Lydersen \& Kovacs 1999). Polar bears (Ursus maritimus) and Arctic foxes (Vulpes lagopus) are the main predators of ringed seals when they are in their lairs (Lydersen \& Gjertz 1986). If snow conditions are poor and the females are forced to give birth on the open ice in Svalbard, the mortality rate of pups increases significantly; the defenceless pups fall prey to glaucous gulls in addition to being taken more easily by foxes and bears (Larus hyperboreus; Lydersen \& Smith 1989). When the pupping and breeding season is over in Svalbard, around late May, the ringed seals go through their annual moulting period, when they replace all their hair and the outer layers of the skin. Moulting peaks in early June, with some temporal spread among the various age and sex groups (Carlens et al. 2006). Availability of a haul-out platform is very important for this process to occur in an energetically efficient manner, and for ringed seals the preferred platform is ice. When the moulting season is over, ringed seals in Svalbard either move offshore seeking areas containing $40-80 \%$ ice coverage or remain coastal, spending their time near tidal glacier fronts (Freitas et al. 2008; Hamilton et al. 2015, 2016). Both areas provide high concentrations of food and access to ice-platforms

CONTACT Christian Lydersen lydersen@npolar.no ENorwegian Polar Institute, Fram Centre, Langnes, Tromsø NO-9296, Norway 
(either in the form of sea ice or glacier ice) to rest. Offshore seals leave the pack-ice areas late in the autumn, even if ice conditions are still favourable, reflecting their need to return to the overwintering/ breeding areas in the fjords of Svalbard before freezeup. The ringed seals that remain close to the coast are already close to their overwintering/breeding habitat and simply become more sedentary as winter approaches. Sub-adult ringed seals tend to adopt the offshore strategy, while larger adult animals tend to stay coastal (Hamilton et al. 2015, 2016).

During the last decade, influxes of Atlantic Water (Cottier et al. 2005) with increasingly higher temperatures (Spielhagen et al. 2011) have replaced Arctic Water masses in the fjords on the west coast of Svalbard. Consequently, sea ice has formed late in the season or in some years has not formed at all (Lydersen et al. 2014). When sea ice forms late in the season there is generally not time for enough snow to accumulate, preventing ringed seals from being able to construct birth lairs. In recent years, the few areas that did have sea-ice in April have had unnaturally high densities of ringed seals. Most pups that have been born on the open ice have been killed by predators. In addition, very little sea ice has been available for the post-breeding moulting period over the past decade as well, forcing some ringed seals to undergo this process in the water with increased energetic costs due to increased heat loss.
During the last few years, local tour operators and trappers have reported ringed seals hauled out on shore. Upon review of photographs taken of these seals, the reports have often turned out to be misidentified harbour seals (Phoca vitulina). However, in some few areas, the reports have proven to be ringed seals that have started using intertidally exposed rocks as resting platforms. Adolfbukta (Fig. 1) is one such area, where ringed seals are now using rocks during low tide in the sea-ice free season for haul-out (Fig. 2a). During the summer of 2016, ringed seals used intertidal mudflats in a lagoon in St Jonsfjorden as a haul-out platform (Fig. 1). These areas were shared with harbour seals (Fig. 2b). This lagoon has been utilized as a capture site for ringed seal tracking studies in the past (in 1996, see Gjertz et al. 2000, and in 2012, see Hamilton et al. 2015; Hamilton et al. 2016), but terrestrial haul-out has never before been observed in this area, nor have harbour seals been observed previously. Four ringed seals instrumented with GPS Satellite Relay Data Loggers (Sea Mammal Research Unit, University of St. Andrews for more details on handling and instrumentation; see Hamilton et al. 2016), in 2012 in this lagoon never hauled out in the lagoon during the seaice-free period (Fig. 3); they hauled out exclusively on glacier ice pieces within the fjord. Such ice platforms are available throughout the sea-ice-free season in this fjord; the tidewater glaciers in the area calve ice

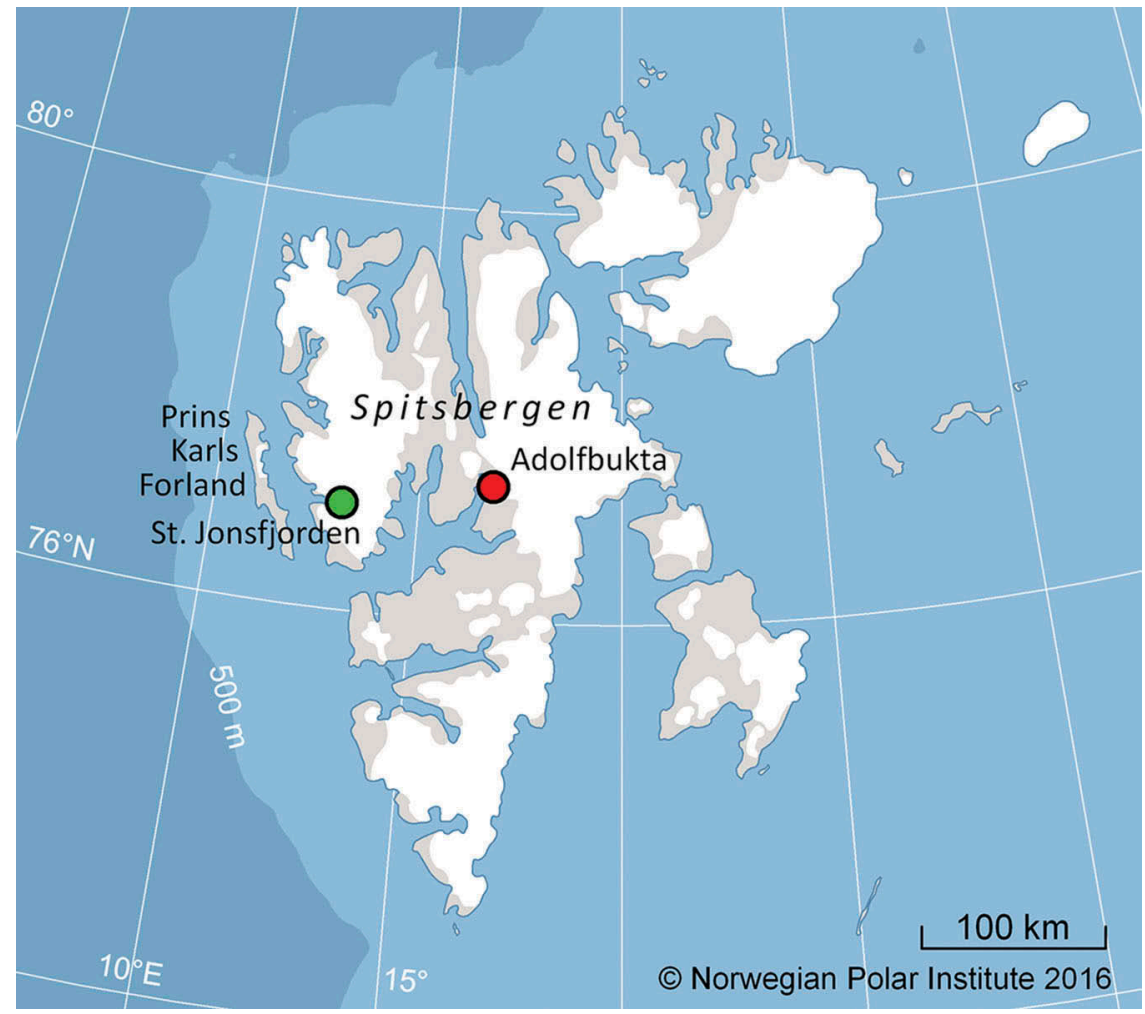

Figure 1. Map of Svalbard where place names mentioned in the text are indicated. The red dot is where the ringed seals in Fig. 2 (a) were hauled out and the green dot is where the mixed group of ringed and harbour seals in Fig. $2 \mathrm{~b}$ were hauled out. 

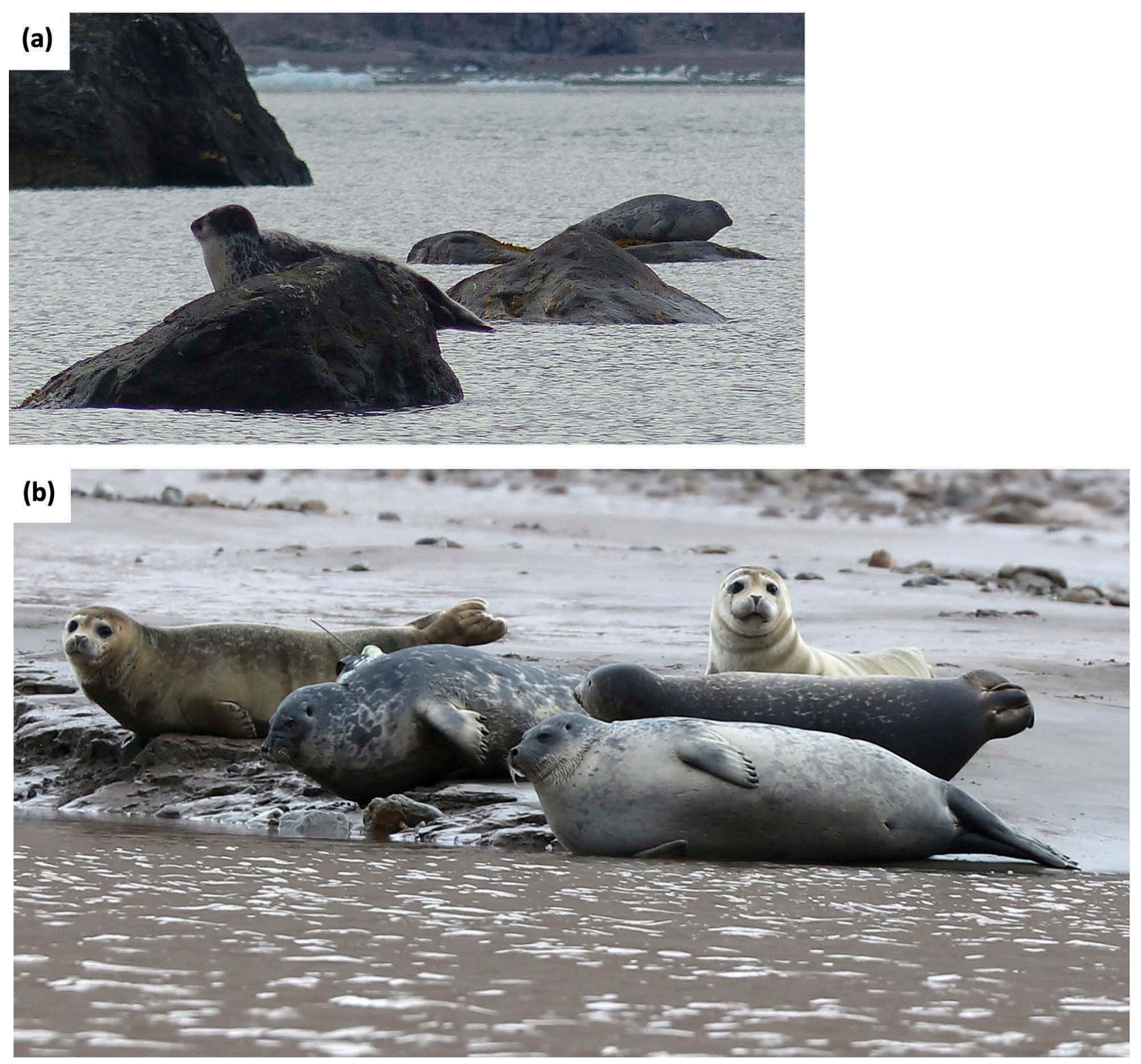

Figure 2. (a) Ringed seals hauled-out on rocks in Adolfbukta, Svalbard; note glacier ice in the background (photo: Anders Voss Thingnes). (b) Three ringed seals (in the foreground - one with a Satellite Relay Data Logger) and two harbour seals in the background hauled out together on shore in St Jonsfjorden, Svalbard; the yellowish fur of the two harbour seals shows that they are still moulting (photo: Guttorm N. Christensen).

pieces routinely. However, these glacier ice pieces never enter the lagoon because of its shallow entrance. It is assumed that the ringed seals come into the lagoon in search of ice platforms (sea ice in lagoons freezes up earlier and stays longer than fjord areas due to fresher water and less wave action) or perhaps food (Arctic char [Salvelinus alpinus]). However, in 2016 all five ringed seals tagged inside the lagoon hauled out on shore within the lagoon, while also using glacier ice deep in the fjord to some degree (Fig. 3). It is worth noting that in 2012, all of the tagged seals returned to the lagoon to haul out late in the season, following the formation of sea ice, which they used as a haul-out platform.

Harbour seals in Svalbard constitute the worlds' northernmost population of this species (Prestrud \& Gjertz 1990; Andersen et al. 2011). A recent study of space use by these seals showed that they had a strong preference for the west side of the Svalbard Archipelago, staying mainly in coastal areas over the continental shelf, and seldom entering the fjord systems (Blanchet et al. 2014). Blanchet et al. (2014) showed that their distribution was largely restricted to coastal areas that were heavily influenced by Atlantic Water. Since both the temperature and influx of this water type is predicted to increase in the future in Svalbard, environmental conditions in the archipelago are expected to become more favourable for harbour seals (Blanchet et al. 2014; Blanchet et al. 2015; Hamilton et al. 2014). Expansion of this "temperate" species is likely to be negative for the Arctic ringed seals, which are already being stressed by reduced breeding habitat and declines of their favoured prey with the on-going borealization of the northern Barents Sea region (Kovacs \& Lydersen 

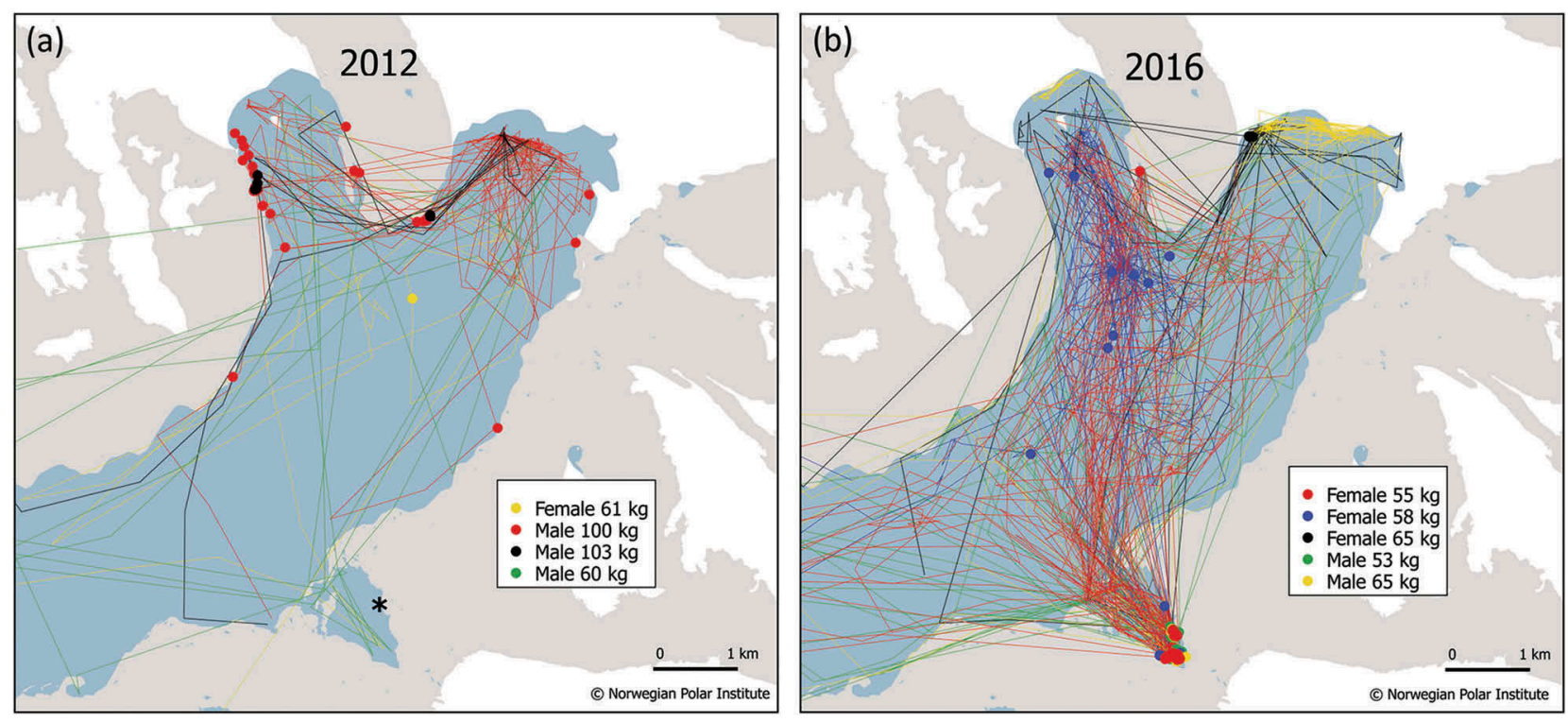

Figure 3. Track (lines) and haul-out sites (circles) for ringed seals equipped with Satellite Relay Data Loggers from capture date (July/August) to 20 September in (a) $2012(N=4)$ and (b) $2016(N=5)$ from the inner parts of St. Jonsfjorden, Svalbard. The end date for the tracks displayed here was set to 20 September to ensure that no ice had yet formed in the lagoon that could be used by the seals as a haul-out platform. The black asterisk in (a) indicates the location inside the lagoon where all seals from both years initially were captured.

2008; Kovacs et al. 2011; Kovacs et al. 2012; Fossheim et al. 2015). Dietary studies conducted in the late 1990s and early 2000s suggested significant overlap in prey types consumed by ringed seals and harbour seals in Svalbard (Andersen et al. 2004; Labansen et al. 2007), but spatial separation of feeding areas likely minimized competition in this earlier period.

Co-habitation of terrestrial haul-out sites by these two species as described here was very surprising. It clearly indications that the two species are no longer spatially separated in the area; harbour seals have extended their range locally into the fjords in western Svalbard. The behavioural plasticity displayed was particularly remarkable for the Arctic ringed seals, which normally do not haul out communally and normally use only ice for haul-out. However, it has been speculated that during these times of dramatic change in ice conditions, some species will likely surprise us, with adaptive flexibility not yet considered possible (Kovacs \& Lydersen 2008). It seems likely that the recent expansion of harbour seals into this area stimulated this new behaviour by the resident ringed seals.

Terrestrial haul-out would at least theoretically solve some issues for ringed seals in a warming Arctic. This substrate could replace sea-ice as a moulting and resting platform. However, terrestrial substrates are unlikely to be successful replacements as a birthing and nursing habitat. Ringed seal pups are small at birth - 4-5 kg (Lydersen 1998) - and dry-cold adapted. They are born in a white furry foetal coat (lanugo) that insulates well in air (i.e., when dry) but not in water and the pups are born with very little subcutaneous fat (Smith et al. 1991; Lydersen et al. 1992). Therefore, exposed pups would be both challenged thermally, and they would be easy prey for avian and mammalian predators. Ringed seal pupping onshore has never been reported from Svalbard. Harbour seal pups in Svalbard on the other hand are born at about 10-12 kg, have shed their lanugo in utero and are born with a subcutaneous blubber layer that enables them to be aquatic from the day they are born (Jørgensen et al. 2001). Despite the malleability in haul-out behaviour illustrated by the observation reported herein, such behavioural plasticity is unlikely to overcome the catastrophic consequences of loss of sea-ice breeding habitats on ringed seal pup survival and population health.

Another question that arises with these new observations of mixed-species haul-out between ringed seals and harbour seals is the potential for hybridization. These two species are currently classified in two separate genera, Pusa and Phoca, respectively (Rice 1998; Berta \& Churchill 2012). Their breeding and moulting phenologies are somewhat different in that ringed seals normally pup in April and moult in May-June (Lydersen 1998), while harbour seals pup in Svalbard in late June and moult in July-August (see Fig. 2b, in which the harbour seals are moulting on 19 July). Both species mate toward the end of the lactation period, which would be May for ringed seals and July for harbour seals - but the likelihood that 
males of both species would be fertile well beyond these time periods is quite high. Cross-breeding has been reported previously between other phocid seal genera (Kovacs et al. 1997), namely Pagophilus (P. groenlandicus, harp seal) and Cystophora (C. cristata, hooded seal), which are morphologically much more dissimilar and have much more divergent mating behaviour than ringed and harbour seals.

This study reports that terrestrial haul-out is now taking place by ringed seals in Svalbard, even in areas where some ice platforms exist. This behaviour is shared with Baltic ringed seals (Härkönen et al. 1998) and freshwater ringed seals found in Lake Saimaa (Pusa hispida saiimensis) and in Lake Ladoga (Pusa hispida ladogensis) (Sipilä \& Hyvärinen 1998). These freshwater seals live in very different environments with different climate and predation pressure compared to the Arctic ringed seals. Nevertheless, it demonstrates some of the adaptive flexibility within ringed seals as a species. The expansion of harbour seals into areas previously occupied only by ice-associated seal species in the Svalbard Archipelago, and the observations reported herein of communal haul-out by ringed seals and harbour seals warrants further study of the ecology of these two species in this area as a model of responses to changing conditions in a warmer Arctic.

\section{Acknowledgements}

We would like to thank Anders Voss Thingnes for providing the photograph in Fig. 2a, and Oddmund Isaksen for help with the fieldwork.

\section{Disclosure statement}

No potential conflict of interest was reported by the authors.

\section{Funding}

This work was supported by the Norwegian Polar Institute's Centre for Ice, Climate and Ecosystems and the Norwegian Research Council.

\section{References}

Andersen L.W., Lydersen C., Frie A.K., Rosing-Asvid A., Hauksson E. \& Kovacs K.M. 2011. A population on the edge: genetic diversity and population structure of the world's northernmost harbour seals (Phoca vitulina). Biological Journal of the Linnean Society 102, 420439.

Andersen S.M., Lydersen C., Grahl-Nielsen O. \& Kovacs K. M. 2004. Autumn diet of harbour seals (Phoca vitulina) at Prins Karls Forland, Svalbard, assessed via scat and fatty-acid analyses. Canadian Journal of Zoology 82, 1230-1245.

Berta A. \& Churchill M. 2012. Pinniped taxonomy: review of currently recognized species and subspecies, and evidence used for their description. Mammal Review 42, 207-234.

Blanchet M.-A., Lydersen C., Ims R.A. \& Kovacs K.M. 2015. Seasonal, oceanographic and atmospheric drivers of diving behaviour in a temperate seal species living in the High Arctic. PLoS ONE 10, e0132686, doi: 10.1371/ journal.pone.0132686

Blanchet M.-A., Lydersen C., Ims R.A., Lowther A.D. \& Kovacs K.M. 2014. Harbour seal Phoca vitulina movement patterns in the High-Arctic archipelago of Svalbard, Norway. Aquatic Biology 21, 167-181.

Carlens H., Lydersen C., Krafft B.A. \& Kovacs K.M. 2006. Spring haul-out behavior of ringed seals (Pusa hispida) in Kongsfjorden, Svalbard. Marine Mammal Science 22, 379-393.

Cottier F., Tverberg V., Inall M., Svendsen H., Nilsen F. \& Griffiths C. 2005. Water mass modification in an Arctic fjord through cross-shelf exchange: the seasonal hydrography of Kongsfjorden, Svalbard. Journal of Geophysical Research-Oceans 110, article no. 12005, doi: 10.1029/ 2004JC002757

Fossheim M., Primicerio R., Johannesen E., Ingvaldsen R. B., Aschan M.A. \& Dolgov A.V. 2015. Recent warming leads to a rapid borealization of fish communities in the Arctic. Nature Climate Change 5(7), doi: 10.1038/ nclimge 2647

Freitas C., Kovacs K.M., Ims R.A., Fedak M.A. \& Lydersen C. 2008. Ringed seal post-moulting movement tactics and habitat selection. Oecologia 155, 193-204.

Gjertz I., Kovacs K.M., Lydersen C. \& Wiig Ø. 2000. Movements and diving of adult ringed seals (Phoca hispida) in Svalbard. Polar Biology 23, 651-656.

Hamilton C.D., Lydersen C., Ims R.A. \& Kovacs K.M. 2015. Predictions replaced by facts: a keystone species' behavioural responses to declining Arctic sea-ice. Biology Letters 11, article no. 20150803, doi: 10.1098/ rsbl.2015.0803

Hamilton C.D., Lydersen C., Ims R.A. \& Kovacs K.M. 2016. Coastal habitat use by ringed seals Pusa hispida following a regional sea-ice collapse: importance of glacial refugia in a changing Arctic. Marine Ecology Progress Series 545, 261-277.

Hamilton C.D., Lydersen C., Ims R.A. \& Kovacs K.M. 2014. Haul-out behaviour of the world's northernmost population of harbour seals (Phoca vitulina) throughout the year. PLoS ONE 9, e86055, doi: 10.1371/journal.pone.0086055

Härkönen T., Stenman O., Jüssi M., Jüssi I., Sagitov R. \& Verevkin M. 1998. Population size and distribution of the Baltic ringed seal (Phoca hispida botnica). NAMMCO Scientific Publications 1, 167-180.

Jørgensen C., Lydersen C., Brix O. \& Kovacs K.M. 2001. Diving development in nursing harbour seal pups. The Journal of Experimental Biology 204, 3993-4004.

Kovacs K.M., Aguilar A., Aurioles D., Burkanov V., Campagna C., Gales N., Gelatt T., Goldsworthy S., Goodman S.J., Hofmeyr G.J.G., Härkönen T., Lowry L., Lydersen C., Schipper J., Sipilä T., Southwell C., Stuart S., Thompson D. \& Trillmich F. 2012. Global threats to pinnipeds. Marine Mammal Science 28, 414-436. 
Kovacs K.M. \& Lydersen C. 2008. Climate change impacts on seals and whales in the North Atlantic Arctic and adjacent shelf seas. Science Progress 91, 117-150.

Kovacs K.M., Lydersen C., Hammill M.O., White B.N., Wilson P.J. \& Malik S. 1997. A harp seal $\mathrm{x}$ hooded seal hybrid. Marine Mammal Science 13, 460-468.

Kovacs K.M., Lydersen C., Overland J.E. \& Moore S.E. 2011. Impacts of changing sea-ice conditions on Arctic marine mammals. Marine Biodiversity 41, 181-194.

Labansen A.L., Lydersen C., Haug T. \& Kovacs K.M. 2007. Spring diet of ringed seals (Phoca hispida) from northwestern Spitsbergen, Norway. ICES Journal of Marine Science 64, 1246-1256.

Lydersen C. 1998. Status and biology of ringed seals (Phoca hispida) in Svalbard. NAMMCO Scientific Publications 1, 46-62.

Lydersen C., Assmy P., Falk-Petersen S., Kohler J., Kovacs K.M., Reigstad M., Steen H., Strøm H., Sundfjord A., Varpe Ø., Walczowski W., Weslawski J.M. \& Zajaczkowski M. 2014. The importance of tidewater glaciers for marine mammals and seabirds in Svalbard, Norway. Journal of Marine Systems 129, 452-471.

Lydersen C. \& Gjertz I. 1986. Studies of the ringed seal (Phoca hispida Schreber 1775) in its breeding habitat in Kongsfjorden, Svalbard. Polar Research 4, 57-63.

Lydersen C. \& Hammill M.O. 1993. Diving in ringed seal (Phoca hispida) pups during the nursing period. Canadian Journal of Zoology 71, 991-996.
Lydersen C., Hammill M.O. \& Ryg M. 1992. Water flux and mass gain during lactation in free-living ringed seal (Phoca hispida) pups. Journal of Zoology, London 228, 361-369.

Lydersen C. \& Kovacs K.M. 1999. Behaviour and energetics of ice-breeding, North Atlantic phocid seals during the lactation period. Marine Ecology Progress Series 187, 265-281.

Lydersen C. \& Smith T.G. 1989. Avian predation on ringed seal Phoca hispida pups. Polar Biology 9, 489-490.

Prestrud P. \& Gjertz I. 1990. The most northerly harbor seal, Phoca vitulina, at Prins Karls Forland, Svalbard. Marine Mammal Science 6, 215-220.

Rice D.W. 1998. Marine mammals of the world. Systematics and distribution. Society of Marine Mammals Special Publication 4. Lawrence, KS: Allen Press.

Sipilä T. \& Hyvärinen H. 1998. Status and biology of Saimaa (Phoca hispida saimensis) and Ladoga (Phoca hispida ladogensis) ringed seals. NAMMCO Scientific Publications 1, 83-99.

Smith T.G., Hammill M.O. \& Taugbøl G. 1991. A review of the developmental, behavioural and physiological adaptations of the ringed seal, Phoca hispida, to life in the Arctic winter. Arctic 44, 124-131.

Spielhagen R.F., Werner K., Sørensen A., Zamelczyk K., Kandiano E., Budeus G., Husum K., Marchitto T.M. \& Hald M. 2011. Enhanced modern heat transfer to the Arctic by warm Atlantic Water. Science 331, 450453. 